\title{
INTERAKSI TANGGUNGJAWAB SOSIAL, KINERJA SOSIAL, KINERJA KEUANGAN DAN LUAS PENGUNGKAPAN SOSIAL (Uji Motif di Balik Social Responsibility Perusahaan Go Publik di Indonesia)
}

Oleh : Nor Hadi

Sekolah Tinggi Agama Islam Negri KUDUS

\begin{abstract}
The research investigated is reciprocal relationship two motives in the corporate social responsibility are social motive and economics motive. The variable of the research are social cost, social performance, economics performance and social disclosure, the have reciprocal relationship. Grand theory of the research are stakeholder and legitimacy theory. The objective of the research are to investigate direct effect and reciprocal effect of research variables. The resulted from the study show that different level of social disclosure. The resulted of hipotetico testing, indicate. (1) direct affect of social cost on social performance $\left(H_{1}\right)$ and social cost on social disclosure $\left(H_{4}\right)$ are significant $(\alpha=0.100)$. (2) the reciprocal and social performance on return social disclosure $\left(H_{6 c}\right)$ and social performance on return on equity $\left(H_{50}\right)$ annual report and hipo annual report and hipotetic testing indicate, motive content (social motive and economics motive) in social responsibility are existed. The motive content are effective, if will be contingent. There are interdependence (reciprocal) relationship. The firm should be based on community excess concept in social responsibility practice.
\end{abstract}

Kata Kunci: Corporate Social Responsibility, Social Cost, Social Disclosure, Social Performance, Financial Performance 


\section{PENDAHULUAN}

\section{Latar Belakang Masalah}

Selama ini, perusahaan dianggap sebagai lembaga yang dapat memberikan banyak keuntungan, seperti: membuka kesempatan kerja, menyediakan barang yang dibutuhkan masyarakat untuk konsumsi, membayar pajak, memberi sumbangan, dan lain-lain (Memed, 2001). Namun dibalik itu, keberadaan perusahaan ternyata juga menimbulkan berbagai persoalan, seperti polusi udara, keracunan, kebisingan, diskriminasi, pemaksaan, kesewenang-wenangan, produksi makanan haram, serta bentuk negative externality lain (Harahap, 2004).

Kasus Free Port di Papua, Newmond di Sulawesi, Caltex di Riau, Nike di Amerika, Bhopal di India, Lapindo, serta kasus lain adalah satu bentuk ketimpangan industrialisasi (Wibisono, 2007). Chapra (1983) menuduh, perusahaan merupakan penyebab utama apa yang sekarang disebut kesalahan alokasi sumber daya manusia dan alam. Externalitas, membuat perusahaan memiliki tanggungjawab secara lebih meluas, yaitu sampai pada tanggungjawab sosial dan lingkungan (social responsibility).

Social responsibility merupakan pelebaran tanggungjawab perusahaan sampai lingkungan baik secara fisik maupun psikis (Chapra, 1983). Hal itu, dapat dilakukan misalnya dengan berinvestasi pảda sektor-sektor ramah lingkungan, menjaga keseimbangan eksploitasi, pengolahan limbah (daur ulang limbah), menaikkan pengeluaran-pengeluan sosial (biaya sosial), serta cara lain guna menjaga keseimbangan lingkungan (Memed, 2001).

Secara yuridis formal, pemerintah telah memberikan anjuran terhadap praktik tanggumngjawab sosial bagi perusahaan lewat Undang-undang No. 40 Tahun 2007 tentang Perseroan Terbatas, dan Suat Keputusan Menteri Badan Usaha Milik Negara Nomor KEP-04 /MBU/2007 tentang Program Kemitraan Badan Usaha Milik Negara dengan Usaha Kecil dan Program Bina Lingkungan.

Terdapat gejala empiris menarik yang patut dicermati dan diteliti berkaitan dengan praktik social responsibility, bahwa masih tinggi problematika sosial dan lingkungan akibat eksistensi perusahaan, meskipun dipermukaan perusahaan telah melakukan serangkaian tindakan tanggungjawab sosial terhadap masyarakat dan lingkungan. Menurut hasil penelitian Arieh $A$ Ulmann (1985), Adam. C.H, (2002), Mathews (1995), Clarke. J. dan Gibson-Sweet (1999), Watt dan Zimmerman (1978), Abbot dan Mousen (1979), Ulmann. C.A (1985) menunjukkan bahwa paling tidak kesesenjangan antara kenyataan dengan yang diharapkan social responsibility, dipicu faktor-faktor, seperti: (1) efektifitas social cost yang dikeluarkan perusahaan terhadap legitimasi stakeholders (kinerja sosial); (2) dominasi motif dalam social responsbility, terutama motif ekonomi oleh perusahaan; dan (3) efektifitas keterbukaan (transformasi informasi) terhadap stakeholders.

Dilema efektifitas social cost dalam menciptakan kinerja sosial (social performance) perusahaan (legitimasi stakeholder), memicu perusahaan melakukan kalkulasi trade of cost and benefit, yang merupakan muara dari tarikmenarik kekuatan antara motif ekonomi (economic motive) dengan motif sosial (social motive). Disitu, terjadi tarik-menarik kepentingan, sehingga equality interdependensi motif sosial dan ekonomi menjadi pertimbangan perusahaan dalam melakukan praktik tanggunggungjawab sosial (social responsibility).

Disamping itu, akuntabilitas dan keterbukaan pelaksanaan tanggungjawab sosial ternyata juga memiliki proporsi tersendiri dalam menciptakan legitimasi stalkeholder (pertimbangan apresiasi oleh stakeholder). Hal itu, disebabkan karena keniscayaan keterpisahaan entitas antara perusahaan dan stakeholder (lihat entity concept), sehingga memunculkan asimetri informasi (information asimetry) tentang: apa, bagaimana, dan sejauhmana perusahaan telah bertanggungjawab atas externalities dis-economic yang ditimbulkan Keterbukaan (disclosure) disamping dipandang mengandung konsekuensi biaya yang relatif tinggi, serta risiko yang moderat, seperti : ancaman competoitive advantage, risiko bisnis, risiko investasi dan sejenisnya. Perusahaan selalu menggunakan rasional, bahwa trade of cost benefit dalam keterbukaan (pengungkpan sosial) adalah filosofi yang selalu dipegang.

Atas dasar fenomen empiris dan teoretis sebagaimana dinyatakan diatas, masalah penelitian yang akan di uji dalam penelitian ini adalah:

1. Apakah biaya sosial (social cost) yang dikeluarkan perusahaan mempunyai pengaruh dalam meningkatkan kinerja sosial (social performance?.

2. Apakah perusahaan yang mengeluarkan biaya sosial (social cost), dalam rangka akuntabilitas dan keterbukaan akan nielakukan pengungkapan sosial secara luas (extent of social disclosure)?.

3. Apakah biaya sosial (social cost) yang dikeluarkan perusahaan memiliki konsekuensi ekonomi (economic conscquences) yaitu meningkatkan kinerja keuangan (jinancial performance)?.

4. Apakah iktiikat dan motivasi perusahaan dalam melakukan luas pengungkapan sosial (extent of social disclosure) 
ditentukan oleh kinerja sosial (social performance) yang dicapai perusahaan?.

5. Bagaimanakah keterkaitan aingkat pengungkapan sosial teriaciap kinerja keuangan, apakah bersifat interdepencss.

6. Bagaimanakah pengaruh kinerja sosial (social performance) terhadap kinerja keuangan (financial performance), apakah bersifat interdependen?

\section{KERANGKA TEORETIK DAN HIPOTESIS 1. Kerangka Pemikiran Teoretik \\ Pergeseran paradigma} pertanggungjawaban perusahaan dari shareholders orientation ke stakeholders orientation merupakan satu keniscayaan. Kondisi tersebut muncul akibat dampak negatif (negative externalities) industrialisasi yang semakin meluas. Bergesernya paradigma tersebut, sudah barang pasti menggeser pola pertanggungjawaban perusahaan yang semula hanya diukur secara ekonomi (economic measurement) kearah pertanggungjawaban dengan memperhitungkan faktor sosial (social measurement), yang selanjutnya disebut tanggungjawab sosial (social responsibility).

Teori Legitinasi dan teori stakeholder memberikan kerangka dasar pola pikir penggeseran pengelolaan perusahaan ke stakeholders orientation tersebut. Esensi teori legitimasi menjelaskan bahwa untuk menjamin dan menjaga keberpihakan (legitimasi) stakeholders baik internal maupun eksternal, perusahaan perlu menjamin congruence-si antara keberadaan dan tujuan perusahaan terhadap pengharapan stakeholders (Gray. et al., 1996; Deegan, 2000).

Kerangka pemikiran teoretis dalam penelitian ini sebagai berikut:

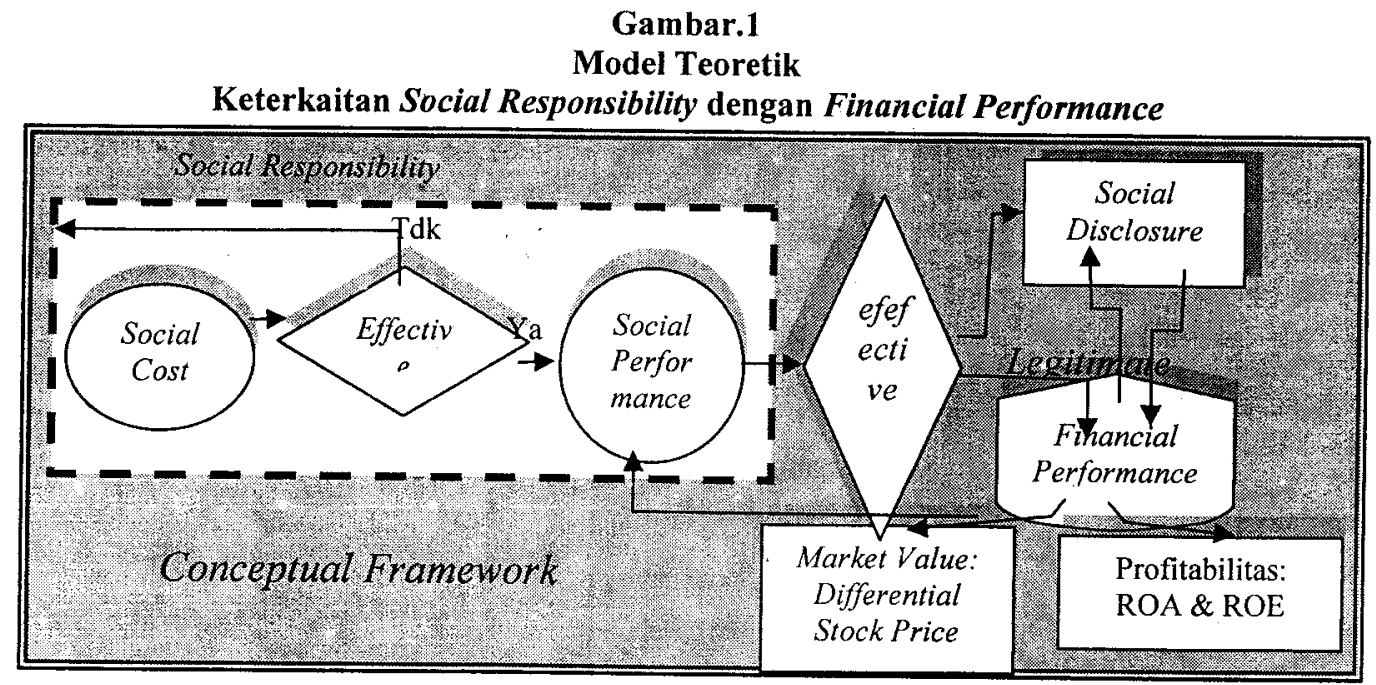

Sumber: Dikembangkan Untuk Penelitian

Gambar teoretik tersebut diatas, memberiklan arahan berpikir logis dari hasil penelitian sebelum serta fenomena empiris, bahwa terdapat ketcrkaitan antara social responsibility dengan kinerja sosial, keuangan dan luas pengungkapan sosial. Disamping itu, juga terdapat keterkaitan antara pengungkapan sosial (social disclosure) dengan kinerja keuangan (differential stock price, ROA \& ROE), yang merupakan value of firm.

\section{Keterkaitan Biaya Sosial Terhadap} Kinerja Sosial dan Keuangan

Hipotesis yang diketengahkan adalah:

$\mathrm{H}_{1}$ :Tingkat biaya sosial (social cost) yang dikeluarkan perusahaan berpengaruh positif terhadap peningkatan kinerja sosial (social performance).

$\mathrm{H}_{2 \mathrm{a}}$ :Tingkat pengeluaran biaya sosial (social cost) perusahaan berpengaruh positif terhadap peningkatan kinerja keuangan perusahaan yaitu return on equity (ROE).

$\mathrm{H}_{2 \mathrm{~b}}$ :Tingkat pengeluaran biaya sosial (social cost) perusahaan berpengaruh positif terhadap peningkatan kinerja keuangan perusahaan yaitu return on assets (ROA).

$\mathrm{H}_{2 \mathrm{c}}$ : Tingkat pengeluaran biaya sosial (social cost) perusahaan berpengaruh poisitif terhadap peningkatan kinerja keuangan (market value) perusahaan yaitu differential stock price.

\section{Pengaruh Biaya Sosial Terhadap Pengungkapan Sosial} adalah: 
$\mathrm{H}_{3}$ : Tingkat pengeluaran biaya sosial (social cost) berpengaruh positif terhadap ketersediaan melakukan pengungkapan sosial secaro luas (extent of social disclosure)

4. Keterkaitan Kinerja Sosial Terhadap Pengungkapan Sosial dan Kinerja Keuangan

Hipotesis yang diketengahkan, adalah:

$\mathrm{H}_{4}$ : Tingkat kinerja sosial (social performance) yang dicapai perusahaan berpengaruh positif terhadap ketersediaan melakukan pengungkapan sosial secara luas (extent of sosial disclosure)

Hipotesis penelitian yang ketengahkan, adalah:

$\mathrm{H}_{5 \mathrm{a}}$ : Tingkat kinerja sosial (social performance) berpengaruh timbal-balik (resiprokal) positif terhadap peningkatan kinerja keuangan return on equity.

$\mathrm{H}_{5 \mathrm{~b}}$ : Tingkat kinerja sosial (social performance) berpengaruh timbal-balik positif terhadap peningkatan kinerja keuangan return on assets (ROA).

$\mathrm{H}_{5 \mathrm{c}}$ : Tingkat knerja sosial (social performance) berpengaruh timbal-balik positif terhadap ketercapaian peningkatan kinerja keuangan (market value) yaitu differential stock price.

\section{Keterkaitan Pengungkapan Sosial Terhadap} Kinerja Keuangan

Hipotesis yang diketengahkan adalah:

$\mathrm{H}_{6 \mathrm{a}}$ : Terdapat pengaruh timbal-balik (resiprokal) positif antara luas pengungkapan sosial (extent of social disclosure) terhadap peningkatan kinerja keuangan perusahaan yaitu return on equity ( $\mathrm{ROE}$ ).

$\mathrm{H}_{6 \mathrm{~b}}$ : Terdapat pengaruh timbal-balik (resiprokal) positif antara luas pengungkapan sosial (extent of social disclosure) terhadap peningkatan kinerja keuangan yaitu return on assets (ROA).
$H_{6 c}$ : Terdapat pengaruh timbal-balik (resiprokal) positif antara luas pengungkapan sosial (extent of social disclosure) terhadap peningkatan kinerja keuangan (market value) yaitu differential stock price.

\section{METODE PENELITIAN}

\section{Jenis dan Sumber Data}

Data yang digunakan dalam penlitian ini adalah data primer dan data sekunder.

\section{Populasi, Sampel dan Teknik Sampling}

Populasi penelitian meliputi seluruh perusahaan yang go publik dibursa efek Indonesia non industri keuangan. Teknik sampling yang dihgunakan adalah purposive sampling

\section{HASIL DAN PEMBAHASAN PENELITIAN}

\section{Gambaran Umum Perusahaan}

Penelitian kali ini dilakukan pada perusahaan go publik di Bursa Efek Indonesia dalam berbagai industri, kecuali perusahaan yang berada pada industri keuangan (financial industries).

Jumlah sampel perusahaan yang dimasukkan dalam unit analisis sebanyak 62 perusahaan yang terdistribusi kedalam delapan industri meskipun kurang proporsional.

\section{Hasil Pengujian Hipotesis}

Adapun hasil pengujian hipotesis tersebut dijelaskan secara lebih rinci dalam tabel sebagai berikut :

Tabel. 1.

Pengujian Hipotesis Pengaruh Langsung

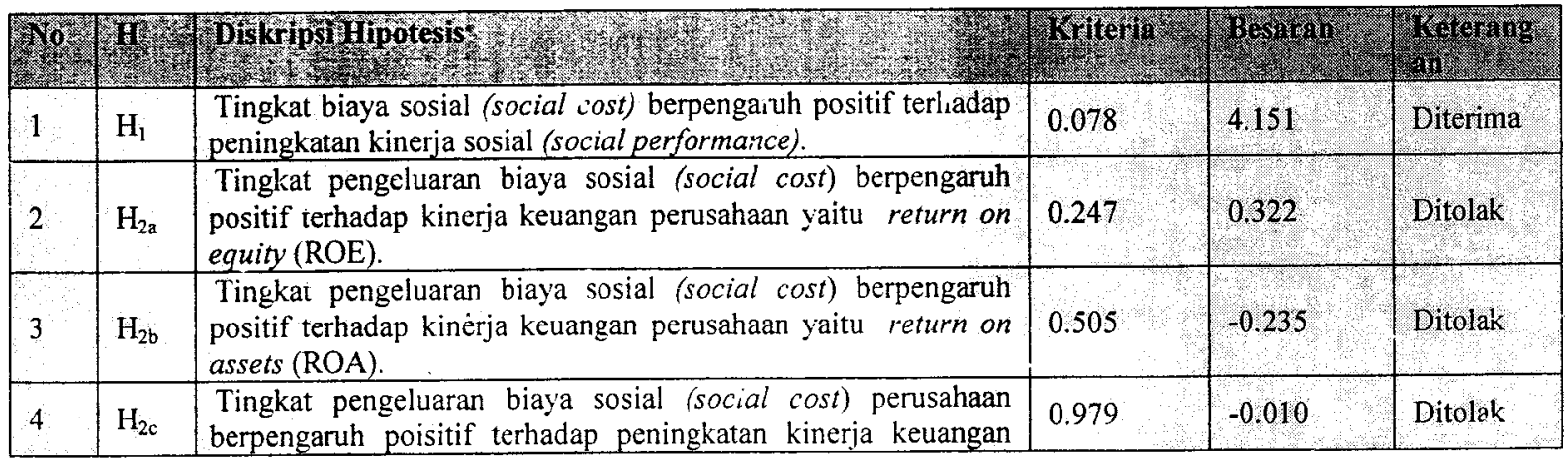




\begin{tabular}{|c|c|c|c|}
\hline & & differential stock price. & \\
\hline 5 & $X_{3}$ & $\begin{array}{l}\text { Tingkat pengeluaran biaya sosial (social cost) perusahaan } \\
\text { berpengaruh positif terhadap pengungkapan sosial (extent of } \\
\text { social disclosure). }\end{array}$ & Diterima \\
\hline 6 & $\mathrm{H}_{4}$ & $\begin{array}{l}\text { Tingkat kinerja sosial yang dicapai perusahaan berpengaruh } / \text { la } \\
\text { positif terhadap ketersediaan melakukan pengungkapan sosial } 1,308 \\
\text { secara luas. }\end{array}$ & Pitolak \\
\hline
\end{tabular}

Sumber: Output SEM

Tabel 1. tersebut diatas menunjukkan bahwa biaya sosial yang dikeluarkan perusahaan sebagai wujud tingkat tanggungjawab sosial ternyata berpengaruh secara signifikan dalam meningkatkan kinerja sosial (social performance) $\left(\mathrm{H}_{1}\right)$. Hal itu berarti, bahwa biaya sosial dapat meningkatkan legitimasi, yaitu menurunkan klaim stakeholders baik terkait lingkungan, energy, community, product dan lainnya. Disamping itu, perusahaan yang melakukan pengorbanan sosial (social responsibility) ternyata juga termotivasi untuk melakukan akuntabuilitas dan keterbukaan lewat pengungkapan sosial dalam annual report $\left(\mathrm{H}_{3}\right)$ (lihat Tabel. 1).

Namun hasil pengujian pengaruh kinerja sosial terhadap ketersediaan melakukan pengungkapan sosial, ternyata menujukkan tidak signifikan $\left(\mathrm{H}_{4}\right)$ (lihat Tabel 1.). Hal itu berarti bahwa tingkat kinerja sosial (kecil klaim stakeholders terhadap perusahaan) ternyata tidak terdapat keterkaitan. Kinerja sosial yang dicapai bukan karena keberpihakan perusahaan terhadap stakeholders semata, melainkan lebih karena tipe stakeholders yang bersifat silent. Faktor lain adalah kurang efektifitas annual report dalam menyanipaikan informasi, terutama bagi stakeholders ekternal yaitu masyarakat (community).

Hasil pengujian serupa terjadi pada pengaruh antara biaya sosial (social cost) terhadap kinerja keuangan (financial performance) baik yang ditunjukkan return on assets (ROA), return on equity (ROE) maupun differential stock price menunjukkan hasil tidak signifikan $\left(\mathrm{H}_{2 \mathrm{a}}\right.$, $\mathrm{H}_{2 b}, \mathrm{H}_{2 \mathrm{c}}$ ) (lihat Tabel 1.). Hal itu menunjukkan bahwa keberpihakan perusahaan lewat berbagai dimensi biaya sosial kurang memiliki konsekuensi ekonomi (economic consequences). Kontek seperti itu terjadi, karena bentuk, tipe, strategi social cost yang dilakukan perusahaan lebih bersifat indirect effect. Perusahaan melakukan tanggungjawab sosial lewat berbagai pengorbanan sosial (social cost) lebih dilihat dan berangkat dari perspektif dan motif manajemen, dan kurang meperhatikan dan memperhitungkan kebutuhan stakeholders, terutama stakeholders eksternal. Sementara hasil pengujian hipotesis yang bersifat resiprokal (timbal-balik) ditunjukkan dalam tabel 2, sebagai berikut:

Gambar 1.

Hasil pengujian model empiris

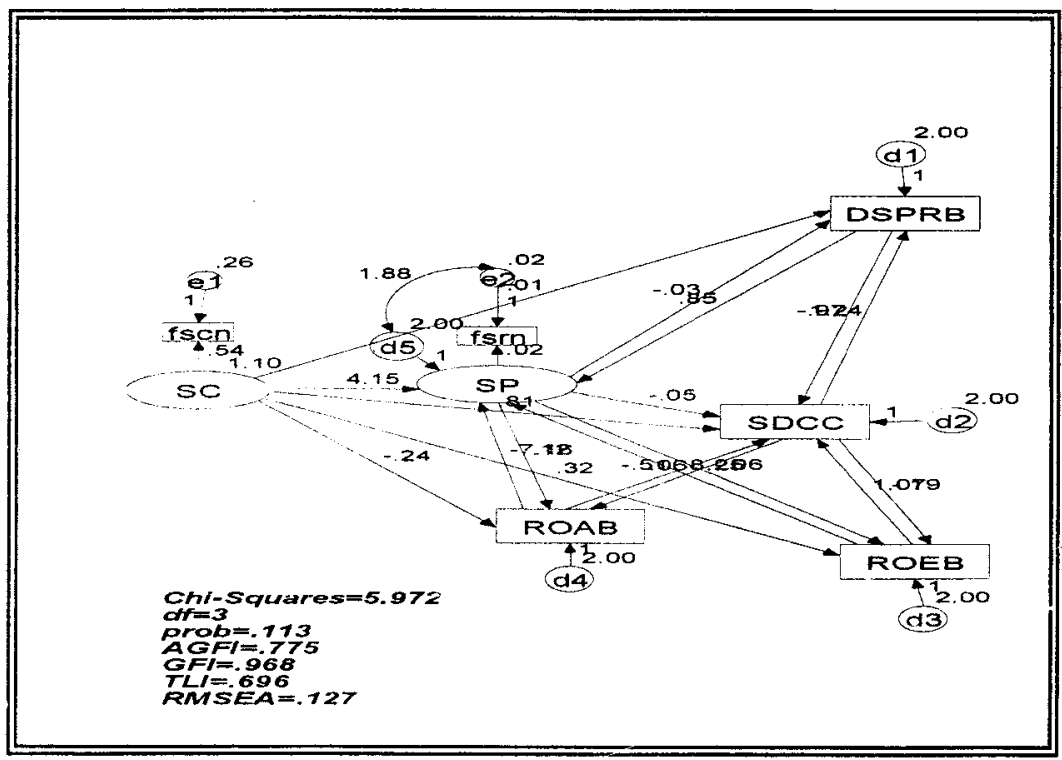


Tabel. 2.

Rangkuman Hasil

Pengujian Hipotesis Pengaruh Timbal-balik

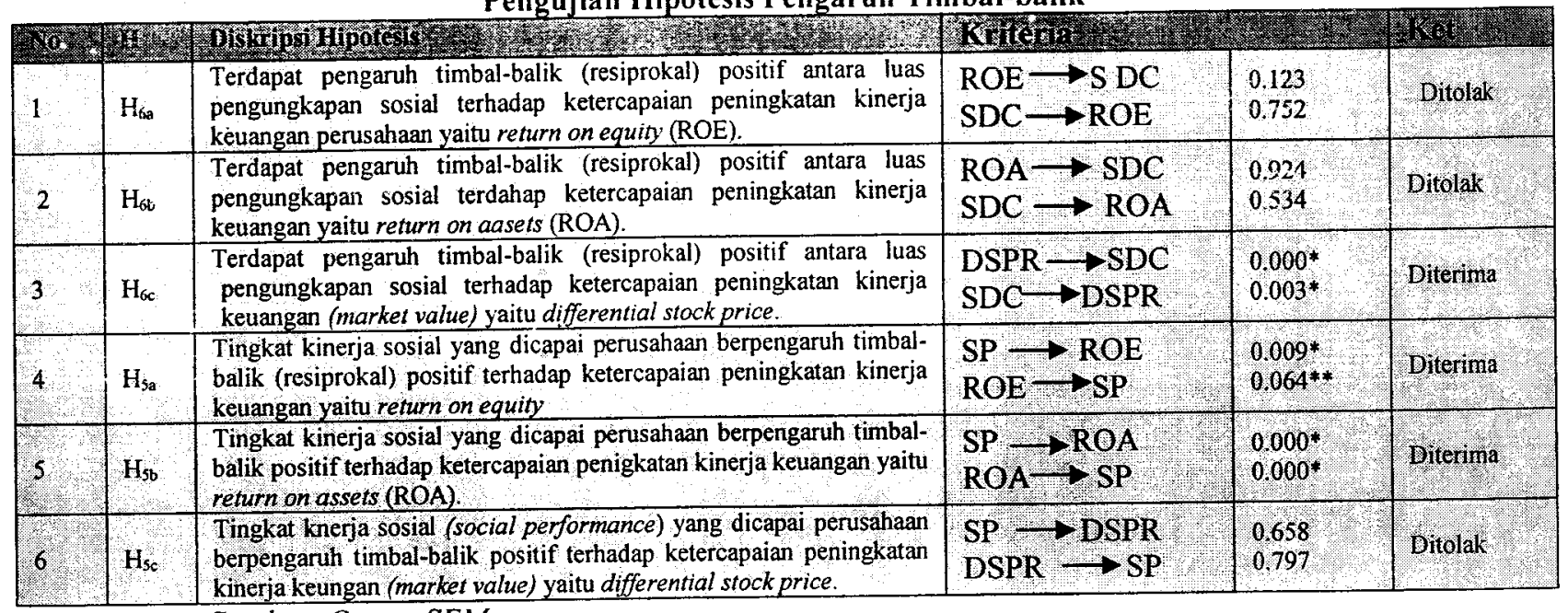

Sumber: Output SEM

Tabel 2. tersebut diatas menunjukkan bahwa hipotesis yang menyatakan bahwa terdapat pengaruh timbal-balik antara pengungkapan sosial terhadap kinerja keuangan, terutama profitabilitas yaitu return on assets (ROA) dan return on equity ( $\mathrm{ROE}$ ) ternyata tidak signifikan $\left(\mathrm{H}_{6 \mathrm{a}}\right.$ dan $\left.\mathrm{H}_{6 \mathrm{~b}}\right)$. Hal itu berarti bahwa pengungkapan sosial lewat annual report merupakan informasi yang kurang efektif dan favorable, terutama bagi stakeholders non investor. Umumnya, stakeholders tersebut kurang memahami dan bahkan bersifat silent. Sehingga, cakupan luas pengungkapan sosial dalam annual report bukan menjadi pertimbangan dalam melakukan afiliasi dengan perusahaan.

$\mathrm{Ha}$ itu berbeda dengan stakeholders investor, dimana social disclosure tetap dijadikan informasi penting dalam pengambilan keputusan, disamping pertimbangan lainnya. Dipihak lain, manajemen juga menggunakan annual report sebagai salah satu media untuk melakukan responsibilitas dan keterbukaan. Sebagai bukti empiris, hasil aji hipotesis yang menyatakan terdapat pengaruh timbalbalik antara pengungkapan sosial terhadap differential stock price menunjukkan signifikan $\left(\mathrm{H}_{6 \mathrm{c}}\right)$ (lihat tabel 2)

Pengujian empiris pengaruh timbalbalik antara kinerja sosial (social performance) terhadap kinerja keuangan return on equity dan return on assets $\left(\mathrm{H}_{6 \mathrm{a}}\right.$ dan $\mathrm{H}_{6 \mathrm{~b}}$ ) (lihat tabel 2) menunjukkan signifikan. Hal itu, menunjukkan bahwa terdapat interdependen motif, baik social maupun economic motive. Kondisi perusahaan yang legitimate, mendukung ketercapain peningkatan profitabilitas sehingga memberikan kemampuan pengembalian investasi dan kesejahteraan pemilik.

Hal itu berbeda dengan hasil pengujian pengarih timbal-balik antara kinerja sosial (social performance) terhadap differential stock price, dimana menunjukkan tidak signifikan $\left(\left(\mathrm{H}_{5 \mathrm{c}}\right)\right.$ (lihat tabel 2). Hal itu mengandung makna, bahwa atmosfir bisnis kondusif tetap menjadi peretimbangan investor namun tidak favorable, umumnya lebih mengejar capital gains dan menggunakan pertimbangan pragmatisme jangka pendek.

\section{KESIMPULAN DAN SARAN}

\section{Kesimpulan}

Adapun kesimpulan hasil penelitian, dinyatakan, sebagai berikut:

a. Tingkat biaya sosial (social cost) yang dikeluarkan mengandung kemanfaatan untuk meningkatkan kinerja sosial, vaitu menurunkan klaim (tuntutan) stakeholders terhadap perusahaan.

b. Dalam rangka akuntabilitas dan keterbukaan perusahaan perlu melakukan keterbukaan, termasuk biaya sosial yang tekah dikeluarkan.

c. Biaya sosial yang dikeluarkan perusahaan tidak berpengaruh dalam 
peningkatan kineria keuangan perusahaan, baik yang ditunjukkan return on assets, return on equity maupun differeriial stock price. Ketidakefektifan daiam mendikung peningkatan kinerja keuangan, mengingat pembebanan biaya sosial oleh perusahaan kurang memperhitungkan ketepatan isi, strategi pembebanan terhadap kesesuaian dengan objek yang dibiayai.

d. Kinerja sosial (social performance) berpengaruh terhadap return on assets (ROA) dan return on equity (ROE). Sementara, pengaruh kinerja sosial (social performance) terhadap differential stock price menunjukkan tidak signifikan. Hal tiu menunjukkan adanya perbedaan cara pandangan, pemahaman, pemaknaan dan kepentingan social responsibility antara manajemen, stakeholders investor dan stakehoders non investor, terurama masyarakat dan konsumen (pelanggan).

e. Pengujian empiris pengaruh timbalbalik (resiprokal) antara kineja keuangan return on assets (ROA) dan return on equity (ROE) terhadap pengungkapan sosial menunjukkan tidak signifikan. Sementara pengujian timbal-balik (resiprokal) antara pengungkapan sosial (social disclosure) terhadap kinerja keuangan differential stock price menunjukkan signifikan. Terdapat perbedaan cara pandang dan ketepatan media pengungkapan antara investor dan stakeholders non investor. Disini penting adanya ketepatan media tranformasi informasi.

f. Pengujian empiris pengaruh timbalbalik (resiprokal) antara kinerja sosial (social performance) terhadap return on assets (ROA) dan return on equity (ROE) menunjukkan signifikan. Bebeda dengan stakeholders non investor (konsumen, supplier, masyarakat dan

\section{DAFTAR PUSTAKA}

Abbot, WF, and Monsen, RJ. 1979. "On the Measurement of Corporate Social Responsibility: Self-Reported an Methode of Measurement Corporate Social Involvement", Academy of Management Journal, Vol. 22, pp. 501-15.

Adams. C.A., 2002. "Internal Organizational Factors Influencing Corporate Social and Ethical lainnya), investor merupakan pihak yang rasional sehingga keputusan investasi tidak sebatas didasarkan pada pertimbangan perusahaan (emiten) yang jauh (kecil) dari klaim stakeholders (social performance bagus).

\section{Saran Untuk Penelitian Selanjutnya}

Melihat dari proses, hasil dan keterbatasan yang ada pada penelitian ini, beberapa saran untuk penelitian selanjutnya, antara lain:

1. Disarankan peneliti selanjutnya untuk melihat secara lebih dalam pada kontek industri tertentu, sehingga mampu memberikan rekomendasi yang lebih tajam dalam memecahkan masalahih praksis.

2. Disarankan agar penelitian selanjuntnyaa meninjau kembali ukuran variabel biaya sosial (social cost), dan kinerja keuangan (financial performance), sehingga dapat memberikan penegasan pengaruh antar variabel tersebut.

3. Ukuran variabel kinerja sosial (social performance), sebaiknya digunakan indeks kinerja sosial perusahaan yang komprehensif, yang disurvey dengan menggunakan instrukmen khusus (kembangkan instrumen pengukuran), dengan melibatkan responden ekesternal.

4. Penelitian ini lebih menitik beratkan pada sisi manajemen (perusahaan), dianjurkan penelitian selanjutnya untuk meneliti dari sisi stakeholders eksternal atau mixed antara kedua sisi (manajemen dan stakeholders eksternal)

5. Penelitian belum melihat secara mendalam tentang efektifias praktik tanggungjawab sosial (social responsibility) serta dimensi ukuran efektifitas, untuk itu penelitian selanjutnya disarankan untuk meneliti wilayah tersebut

Reporting Beyond Current Theorizing" Accounting, Auditing and Accountability Journal. Vol. 15. No. 2

Adam, C.A., 2004, "The Ethical, Social and Environmental performance reportinggap" Accounting \& Auditing Journal. Vol.17. pp. 731-575

Anderson, J,C, and Frankle, A.W. 1980. "Voluntary Social Reporting: An Iso-Beta Portfolio Analysis". The 
Accounting Review. Vol. 55, pp 468-79.

Belkaoui, A. 1978. "The Impact of the Disclosure of the Environment Effects of Organization Behavior on the Market". Financial Management. Vol. 5 No. 4, pp.2631

Belkaoui. A., 1976. "The Impact of the Disclosure of the Environmental Effects of Organizations Behaviour on the Market". Financial Management, Vol. 5. PP. 26-31.

Campbell, D.j. 2000. "Legitimacy Theory or Managerial Reality Construction? Corporate Social Disclosure in Marks and Spencer Plc Corporate Report, 1969-1997'. Accounting Forum. Vol. 24. No. 1

Chapra, Umer. 1992. Islam and The Economics Challenge. The Islamic Foundation. London.

Clarke, J. and Gibson-Sweet, M. 1999. “ The Use of Corporate Social Disclosure in The Management of Reputation and Legitimacy: A Cross Sectoral Analysis of UK Top 100 Companies". Business Ethics: A European Review. Vol. 8. PP. 513

Deegan, C. 2000. Financial Accounting Theory. Rosevill, NSW: McGrawHill.

Deegan, C. 2002. "Introduction-The Legitimizing Effect of Social and Environmental Disclosur ${ }^{\circ}-\mathrm{A}$ Theoretical Foundation". Accounting, Auditing and Accountability Journal. Vol. 15. pp. 182-311

Deegan. C, Rankin. M, Tóbin. J. 2002. "An Examination of the Corporate Social and Environmental Disclosure BHP from 1983-1997 a Test of Legitimacy Theory". Accounting, Auditing and Accountability. Vol, 15, No 3, pp 312343

Elliot, Robert, K. and Peter D. Jacobson. 1994. "Cost of Benefit of Business Information Disclosure". Accounting Horizon. Vol. 8. (Des). pp. $80-99$

Epstein, E.M. 1989. "Business Ethics, Corporate Good Citizenship and the
Corporate Social Policy Process: A View from The United States". Journal of Business Ethics. Vol. 8. pp. 583-595.

Florence Devina, L. Suryanto dan Zulaikha 2004. "Pengaruh Karakteristik Perusahaan terhadap Pengungkapan Sosial dalam Laporan Tahunan Perusahaan Go Publik di Bursa Efek Jakarta". Jurnal Maksi, Vol 4.

Friedman, M. 1970. "The Social Responsibility of Business in to increase its profit". New York Time Magazine. 13 September 1970. pp. 32-126.

Gray, R., Kouhy. R, \& Lavers. S. 1995. "Corporate Social and Environmental Report". Accounting and Auditing Journal. Vol. 8. No 2. pp. 47-77.

Harahap, Sofyan S, 2001. Menuju Perumusan Akuntansi Islam. Pustaka Quantum Jakarta

Ingram, R.W. and Frazier, K.B. 1983. "Environmental Performance and Corporate Disclosure". Journal of Accounting Research. Vol. 18. pp. 614-60.

Johnson, H.I., 1979. Disclosure of Corporate Social Performance, Preger, Yew York.

Kaplan, R dan Atkinson, A . Advanced Management Accounting. $3 \mathrm{rd} \mathrm{ed}$, Printicw Hill. Inc.

Kartana. Hari. 2001. Dimensi Perubahan dalam Implementasi Good Corporate Governance. makalah seminar nasional akuntansi Indonesia diselenggarakan oleh IAI KAP dan IAI KAM.

Kah Hin Khor. 1985. "Social Contract Theory, Legitimacy Theory and Corporate Social and Environmental Disclosure Policies: Constructing a Theoritical Framework", Academiy of Management Review. Vol. 10. No.3

Kedia, B.L, and Kuntz, E.C. 1981. The Contest of Social Performance: An Empirical Study of Texas Banks", in Preston, L.E. (E.d), Research in Corporate Social Performace and 
Policy. Vol. III, jai Press, Greenwich, CT, PP. 133-54

Mathews. M.R., 1984. Exploring The Philosopical Bases Underlying Social Accounting. Journal of Accounting and Finance Discussion Paper. No. 3, Massey University.

Memed Sueb, 2001, Pengaruh Akuntansi Sosial terhadap Kinerja Sosial dan Keuangan Perusahaan Terbuka di Indonesia. Disertasi Universitas Padjadjaran Bandung.

Mathews, M.R., 1997, "Twenty-five years of Social and Environmental Accounting Research, is There a Silver Jubblee to Celebrate?" Accounting, Auditing and Acountability.Vol. 10:4. pp. 481531

Meyer, J.W. and Rowan, B. 1977. "Institutionalized Organizations: Formal Structure as Myth and Ceremony". American Journal of Sociology.. Vol. 83. pp. 340-363

Muhadjir. Noeng 2002. Metodologi Penelitian Kualitatif. Rake Sarasin Yogyakarta

Nicholls, D. and Hamed, K 1995 "Disclosure Quality in Corporate Annual Report on Non-Financial Companies in . Bangladesh". Research in Accounting in Emerging Economics. Vol.3,: 149170

O'Donovan, G. 2002. "Environmental Disclosure in the Annual Report: Extending the Aplicability and Predictive Power of Legitimacy Theory". Accounting, Auditing \& Accountability Journal. Vol. 15. No. 3. pp. 344-371.

Preston, L.E 1978. "Analysis Corporate Social Performance: Methode and
Result". Journal of Contemporary

Business. Spring, pp. 158-73

Subroto. P.H .2002. A Correlational Study of Corporate Social Responsibility and Financial Performance an Empirical Survey Toward Ethical Business Practice in Indonesia. Dissertation Capella University.

Spicer, B. 1978. "Investors, Corporate Social Performance and Information Disclosure, an Empirical Study". The Accounting Review. h. $94-111$

Shane, P.B. \& Spicer, B.H, 1983), “ Market Response to Environmental Information Produced Outside the Firm". Accounting Review. Vol. 58 , h. 521-538.

Ullmann. A.R, 1985, " Data in Search of a Theory: A Critical Examination of the Relationships Among Social Performance, Social Disclosure, and Economic Performance of U.S. Firm". Academy of Management. Vol. 10. No, 3, 540-557

Watt, R.L. dan Zimmerman.J.L. 1986. Positive Accounting Theory. Prentice Hall,

Wartick, S. \& Cochran, P. 1985. "The Evolution of the Corporate Social Performance Model". Academy of Mnagement Review. Vol. 10. pp. 758-769.

Wibisono, Yusuf. 2007. Membedah Konsep dan Aplikasi Corporate Social Responsibility. Fascho Publishing. Jatim.

\begin{tabular}{llr} 
Zegal, & \multicolumn{1}{c}{ Sadrudin, Ahmed. } & 1984. \\
"Comparison of & Social \\
Responsibility & Information \\
Disclosure Media & Used by \\
Canadian Firm". $\boldsymbol{A A A J}$. & 3,1
\end{tabular}

